\title{
Mas
}

\section{Role of Alternative Media in Empowerment of Women}

\section{Geeta Kashyap*}

Assistant Professor, Lovely Professional University, Phagwara, India

"Correspondence author: Geeta Kashyap, Assistant Professor, Lovely Professional University, Phagwara, India, Tel: 9876029177, E-mail: geetakashyap. 87@gmail.com

Rec Date: Jun 23, 2014; Acc Date: July 23, 2014; Pub Date: July 23, 2014

Copyright: ( 2014 Kashyap G. This is an open-access article distributed under the terms of the Creative Commons Attribution License, which permits unrestricted use, distribution, and reproduction in any medium, provided the original author and source are credited.

\begin{abstract}
Alternative media is becoming a platform for the empowerment of the society on a whole. Women have got in this way a new space to share their views. This virtual space is giving her power by segregating from the real space; where she has to face the real challenges in the form of eve-teasing, stalking, harassment etc.

Private settings in the social networking sites must be very popular among the Indian girls, who face stalking as obvious crime. Private settings have provided a shelter to the girls at social network sites to distract unwanted attention. It might have allowed many girls to sign in into the social networking sites besides it also reflects the complications of real world that alternative media allow girls to avoid online. It would be interesting to study the private settings of a group of girls and boys of any class. How differently these setting are being used by boys and girls.
\end{abstract}

The research paper focuses on whether alternative media is helping in empowering women where she feels free to share anything she wants or still she feel restricted with the social bounding.

Keywords: Gender sensitization; Social networking sites; New media; Women empowerment

\section{Introduction}

Gender sensitization has always remain a vital issue in India, where patriarchal society still exists. Women are always subject to risks whenever they want to move out in society freely. The issue like Delhi gang rape shows the insensitivity of men towards women. The eveteasing is a common phenomenon with Indian women and now they have learned to live with it. We can even say, it is now the part of their common life. Ignorance is bliss and they have adopted it. The working women are more risk-prone.

Sexual-harassment, eve-teasing and stalking are the common issues which a women faces every day. Icing on the cake, she is always suggested to behave herself in the manner of dressing, talking and she should not be get frank with the males in her surroundings. Society still seems not able to understand the physical and mental condition of women, who faces such kind of misconduct. The search is still on for a space where a woman can feel safe even in $21^{\text {st }}$ century. However, new media seems becoming this space for women.

If we talk about media, violence against women stories are hardly found in media. Women issues and interests are toned down, when it comes to national media. National media is having its own issues related with Indian politics or according to the criteria of TRP. There is hardly any special program which raises the problem of women and provides solution. Media is not having slots to show the programs related to women empowerment.

In the case of Delhi gang rape it was not actually only the mainstream media which has helped in motivating the people for protest, the role was played by new media which is also known as alternative media in present scene. "On Google Trends' search volume index, "Delhi gang rape,"

"Rape in Delhi" and "gang-rape victim" has been among the top search phrases in India over the last week, reaching a peak on December 20. The highest volumes were from Delhi and neighboring states like Uttar Pradesh, Haryana and Rajasthan [1]."

Alternative media is becoming a platform for the empowerment of the society on a whole. Women have got in this way a new space to share their views. This virtual space is giving her power by segregating from the real space; where she has to face the real challenges in the form of eve-teasing, stalking, harassment etc.

Private settings in the social networking sites must be very popular among the Indian girls, who face stalking as obvious crime. Private settings have provided a shelter to the girls at social network sites to distract unwanted attention. It might have allowed many girls to sign in into the social networking sites besides it also reflects the complications of real world that alternative media allow girls to avoid online.

However, the setting provided by social networking sites are common to everyone, but the usage differ according to gender. The social networking sites are known as the platform where people tend to socialize in virtual space. Among the popular social networking sites Facebook, Myspace, Pinterest, Flicker etc. The most popular social networking site is Facebook with near about 92 million users in India.

Keeping a close view on the profiles available on Facebook, a social networking site, depicts that most of the guys have public profile and it is opposite in case of girls. Most of the Guys are using their profile pic without customizing it and girls still feel shilly-shally in placing their original pic. 
In our society there is a still gap between the male and female groups. It is always expected from females to be in a limited space. There are some rules and norms which are expected to be followed up by her only e.g. the night jobs are still not popular among females. Thus, women are empowered is still having a question mark. But with the advent of new media it seems that the scenario is changing today.

\section{Literature Review}

The position of men is more stronger than women, the point has been made strongin a research paper Gender Sensitization: The Bias and Women Victimization in India (2006) by Dhere Amar M., Nikam Balasaheb T. \& Pardeshi Pratapsingh B, it has been discussed The men are always placed in a more advantageous position than women in South and South East Asian region especially in India. Gender, as a determinant of a social relation that legitimizes and sustains men's power over women, is inheritantly about relations between women and men, as well as relations among groups of women and among groups of men. Across differences of class, race, ethnicity, sexuality, age and religion, one of the few commonalities that men share, as a 'distinct group', is their gender privilege [2].

In a blog, The new media and the global women's empowerment movement (2011) by Jammie Victory Abdulai, it has been discussed that what interests me most about this new media is the fact that I can be part of the global information sharing process. That is, I can air out my views without any restraint. It is quite amazing that I can read articles or even news items and share my own views about them [3].

The new media has helped in women empowerment. The point has been discussed in a research paper Women Empowerment: Role of New Media (2013) by Dr. Ehtesham AhmadKhan and Arif Moin, "All over the world, the impact of New media has been witnessed in recent years, with online platforms becoming increasingly powerful mechanisms for mobilising popular support. India is no exception, and the media coverage of this particularly horrific Delhi gang rape case and the online responses changed the mindsets of the youth and it seems that people are no longer willing to accept rape and sexual assault as "a simple fact of life." People in India demanded change, and they used the power of modern media to make their voices heard. In

Delhi gang rape case Platforms such as the Facebook group 'Gang Rape in Delhi' and 'Justice for Raped Girl in Delhi' have united people in expressing their hopes for a future free from similar cases. People raised their voices through Twitter, Face book and other new media, expressing their frustrations against the government and administration [4]."

\section{Method}

To know the status of use of privacy settings on Facebook, a survey was conducted by the researcher among youth to know that what things really drive them to use privacy. The sample taken for this purpose was 50. The sampling method used was quota sampling as 25 boys and 25 girls were included. A questionnaire was formulated and closed ended questions were asked to know the privacy settings used by both genders.

\section{Findings}

There were different questions asked and respondents give their views and those views are discussed as below:
In response to a question asked on whether they are comfortable using Facebook without privacy setting, 92\% of the female said that they are not comfortable using Facebook without privacy settings in comparison to girls, $64 \%$ of the boys said that they are quite comfortable with no privacy settings.

Similarly, in response to the question asked why they customized their profile picture from public, $68 \%$ of the girls said that due online harassment or they have fear of being misused, on the other hand 55\% of the male do not customize their profile pics and $45 \%$ do customize their profile pic due to personal space only.

However, one surprising result was there about the use of original profile picture by girls. Ninety nine percent males use their original profile pics and females showing equivalence $92 \%$ of them also use their original profile pics but with some privacy settings.

Likewise, girls are quite tolerable with exchanging messages as they are using only basic filtering. Only $18 \%$ girls are into strict filtering.

Thus, this is one way of transformation, earlier girls use to hesitate with using original profile pics for any social networking sites. But it is one changing trend. However, they do take some precautions while using it.

Although, when it was asked how many girls have provided their personal contact number on Facebook the answer was as expected $100 \%$ result was in favor of not providing the contact number, whereas boys are quite comfortable as $77 \%$ of them have provided their contact number.

\section{Discussion}

On Facebook, almost $90 \%$ of the females have blocked someone for various reasons. Not providing contact details by the girls depicts their fear and discomfort in the society. It shows the lack of freedom in comparison to males as males have provided their contact details. Those who don't provide the details their reason is different as they want their personal space and not because they feel insecure while sharing it.

There are different reasons given by girls for using privacy settings strictly. The reasons mentioned in the questionnaire includes; fake account, disturbance, misbehave on Facebook, Unknown persons keep on messaging or those with they are no more friends, they talk a lot like irritating (Chipkku), fear of misuse and online harassment, When I don't want them to be my friend anymore I block them, Using foul language \& writing stupid comments on photos \& status, lots of tagging in photo's or commenting baseless.

One response says, "I block people who seem to be pestering me and invading my privacy, I also block people especially boys who do nothing but harass one on Facebook."

This result shows that women still have that same fear on virtual world. They have skepticism about the security and other women related issues. She feels the same harassment over internet also. However, providing email id's is far better option available than the contact number.

Despina Cheema, a young female and regular user of Facebook says, "There would be displeasure in using FB without such privacies, people make fake ids and harass women/girls. This virtual space is surely in favor of women as though not completely but we choose who can tag, message and contact us." 
Citation: Kashyap G (2014) Role of Alternative Media in Empowerment of Women. J Mass Communicat Journalism 4: 209. doi:

Page 3 of 3

\section{Conclusion}

Society is greatly influenced through social networking sites, chats and other applications through which one individual can communicate comfortably to anyone across globe. The debate and discussion based sites are allowing women to participate in these discussions and share grievances also. The information technology has changed a lot the way we used to communicate. Earlier we used have a limited surrounding to share and discuss the issues and problems. But the emerging new media technology has provided a new form of communication where one can talk any individual sitting anywhere in the world. Now there are many who can listen to the problems and feelings of any person.

As a result, from above all it can be said that in some sense yes new media has provided woman with freedom and she feels empowered where she share her feelings, emotion and her thinking, which was earlier not paid much attention. Moreover she is not answerable for saying anything as the wall belongs to her. In this virtual world she is having all freedom where she can add friends according to her choice, communicate with them and sometimes also block them. It also depicts that she is still having a fear that was present in actual social set-up.

\section{Areas for potential research}

- New media and Gender sensitization

- Use of Privacy settings of different social networking sites among public. A comparative study can be done is there any difference in use of privacy settings if change in public is there.

\section{References}

1. Delhi gang rape case: Social media fuels rally at India Gate (2012) The Economic Times.

2. Amar DM, Balasaheb NT, Pratapsingh PB. (2010). Gender Sensitization: The Bias and Women Victimization in India. Earth Exploration.

3. Victory J (2011) The New Media and The Global Women's Empowerment Movement. World Pulse.

4. Khan EA, Moin A (2013) Women Empowerment: Role of New Media. Commonwealth Association for Education, Administration and Management. 